\title{
CONCISE REVIEW: $\beta$ CELL REPLACEMENT THERAPIES IN TREATMENT OF DIABETES MELLITUS
}

\author{
Özge Sezin SOMUNCU ${ }^{1 *}$, Umay ÇELIK ${ }^{2}$, Büşra ERGÜN ${ }^{3}$, Emre ARPALI $^{4}$ \\ ${ }^{1}$ Department of Basic Medical Science, Bahcesehir University Faculty of Medicine, İstanbul, TURKEY \\ ${ }^{2}$ Bahcesehir University Faculty of Medicine, İstanbul, TURKEY \\ ${ }^{3}$ Department of Medical Biochemistry, Acıbadem University, İstanbul, TURKEY \\ ${ }^{4}$ Department of Urology, KOÇ University Hospital, İstanbul, TURKEY \\ *Corresponding author: ORCID ID: orcid.org/0000-0002-0841-8263, e-mail: ozgesezin.somuncu@ vsh.bau.edu.tr
}

Cite this article as:

Somuncu Ö.S., Celik U., Ergün B., Arpalı E. 2019. Concise Review: $\beta$ Cell Replacement Therapies in Treatment of Diabetes Mellitus. Trakya Univ J Nat Sci, 20(Special Issue): S45-S54, DOI: 10.23902/trkjnat.469530

Received: 11 October 2018, Accepted: 21 January 2019, Published: 1 February 2019

\begin{abstract}
Metabolic rate of glucose uptake is generally controlled by a feedback mechanism covering islet $\beta$ cells and insulinsensitive tissues, wherein tissue sensitivity to insulin influences the level of $\beta$-cell comeback. In case of insulin presence, $\beta$ cells preserve standard glucose tolerance via enhancing insulin production. Even though $\beta$-cell dysfunction has a strong hereditary component, environmental alterations carry an important part as well. Current research methods have facilitated to establish the important part of hexoses, amino acids, and fatty acids in the development of insulin resistance and $\beta$-cell dysfunction, therefore more operative treatments to slow the progressive loss of $\beta$-cell function are required. Latest discoveries from clinical research deliver significant information about approaches to stop and treat diabetes and some of the adversative properties of these interferences. Generation of satisfactory numbers of pancreatic endocrine cells that work in the same way as primary islets is of supreme prominence for the expansion of cell treatments to cure. In this study, we focused on different techniques starting from islet and pancreas transplantations individually and ending on new therapies such as stem cell technology and bioengineering. We aimed to establish a comprehensive and detailed explanation of treatment perspectives for islet cell loss. This review is carrying a novel potential for enlightening the current treatments and future-based therapies.
\end{abstract}

Key words: Stem cell therapy, islet cells, pancreas.

Özet: Glikoz alımının metabolik oranı, genellikle adacık hücrelerini ve insüline duyarlı dokuları kapsayan bir geri bildirim mekanizması ile kontrol edilir. İnsülin varlığında $\beta$ hücreleri insülin üretimini artırarak standart glikoz toleransını korurlar. $\beta$ hücre disfonksiyonunda kalıtsal bileșenlerin etkileri yüksek olsa da, çevresel değişikliklerin de önemli bir rol oynadığı gösterilmiştir. Güncel araştırma yöntemleri, insülin direnci ve $\beta$-hücre disfonksiyonunun oluşmasında heksozların, amino asitlerin ve yağ asitlerinin etkilerinin varlığını göstermekle birlikte, hücre fonksiyonunun aşamalı kaybını yavaşlatmak için daha etkili tedavilerin gerekliliğini de göstermektedir. Klinik araştırmalardan elde edilen sonuçlar diyabetin durdurulması ve tedavi edilmesi ve bu müdahalelerin olumsuz özelliklerinden bazıları ile ilgili önemli bilgiler sunmaktadır. Birincil adacık hücreleri ile aynı şekilde çalışan pankreatik endokrin hücrelerinin yeterli sayıda üretilmesi, iyileştirilmesi için hücre tedavilerinin genişletilmesi büyük öneme sahiptir. Bu derlemede, adacık ve pankreas transplantasyonlarından başlayıp kök hücre teknolojisi ve biyomühendislik odaklı yeni tedavi tekniklerinin incelenmesine odaklandık. Adacık hücre kaybı için tedavi perspektiflerinin kapsamlı ve ayrıntılı bir açıklamasını yapmayı amaçladık. Dolayısıyla bu inceleme, mevcut tedavileri ve geleceğe dayalı tedavileri aydınlatmak için açıklayıcı bir potansiyel taşımaktadır.

\section{Introduction}

Diabetes mellitus (DM) is a chronic disease associated with high blood glucose levels and long-term secondary complications characterized by micro-vascular problems such as retinopathy and nephropathy ( Silva et al. 2006, Petersmann et al. 2018). The disease has been conventionally grouped into type I and type II DM depending on the underlying cause. Type I DM is an autoimmune disease caused by the inability of pancreas to produce insulin due to the damage of the insulin secreting $\beta$ cells, while type II DM is caused by insulin production by pancreas below desired levels or insulin resistance of the body, which is commonly caused by obesity (Akinci et al. 2012). Currently, insulin levels are usually maintained with regular injections or continuous infusion of insulin and monitoring of blood glucose levels (Silva $e t$ al. 2006, Petersmann et al. 2018). DM is one of the most prevalent health care problems throughout the world, especially in developed countries. As reported by the World Health Organization (WHO), today 285 million people at minimum suffer from DM. On the other hand, 
the projection about the number of people associated with $\mathrm{DM}$ in 2030 is 439 million (NCD Risk Factor Collaboration 2016). DM prevalence has gradually improved in the aged population in Europe, regarding to the elevated incidence of obesity. The archieves of the Ministry of Health in Turkey reported that, the rate of DM suffering people was $7.8 \%$ in the country by the year 2015. Owing to the excessive quantity of DM patients, Turkey conveys nearly $13 \%$ of the cases of Europe (Oksuz et al. 2017). The estimated prevalence of the disease worldwide is shown in Fig. 1.

Since the first transplantation performed at the University of Minnesota in 1966, pancreas transplantation has been well-established as the treatment of choice for type I DM. Pancreas transplant numbers steadily increased until the beginning of the 2000s except a decrease observed between the period of 2005-2014. Today, transplantation is accepted as the only modality with clearly-defined indications and long-term insulin free patient survival. These current indications defined by the American Diabetes Association are as follows (Assoc 2006):

1- Patients with end-stage renal disease who had or plan to have a kidney transplant,

2- If there is no indication for kidney transplantation, pancreas transplantation should only be considered for the patients who have the following three criteria:

a) A history of frequent, acute, and severe metabolic complications (hypoglycemia, hyperglycemia, ketoacidosis) requiring medical attention,

b) Clinical and emotional problems with exogenous insulin therapy that are so severe as to be incapacitating,

c) Consistent failure of insulin-based management to prevent acute complications (Assoc 2006).

Impact of pancreas transplantation on patient survival has been controversial since there are no prospective randomized studies evaluating the survival benefits of SPK (simultaneous pancreas and kidney), PTA (pancreas transplant alone) or kidney transplantation. However, registry analysis shows comparable patient survival after SPK in relation to living donor kidney transplantation. It has been shown that secondary complications of DM can be prevented or progression of these complications, such as diabetic nephropathy or retinopathy, can be delayed most likely due to normoglycemic status achieved after successful pancreas transplantation (Fioretto et al. 1998).

Transfer of pancreatic islet cells as a possible treatment for type I DM has become the topic of extreme attention over the past two decades. A procedure, identified via the infusion of several new islets subsequent to the host immune suppression with non-steroidal immunosuppressive regimen, has been shown to be effective in severe types of type I DM. Nonetheless, the issue of the worldwide lack of transplant ready islets has yet to be fixed. Furthermore, islet transplantation has been hindered by immune response and repeated attacks towards islets upon fundamental autoimmunity (Halpin et al. 2017).

Immunosuppressive routines are effective in stopping islet failure for months to years, therefore these treatments may upsurge the possibility for specific malignancies and unscrupulous infections. Paradoxically, all ordinarily used immunosuppressive medication covering steroids or calcineurin inhibitors have been stated to have opposing effects on pancreatic $\beta$ cells (Shapiro et al. 2000, Hafiz et al. 2005). Consequently, these influences encourage strategies to find renewable bases for islet replacement tissue. However, immunological and technical barriers seem to hinder the widespread utilization of this treatment modality (Halpinet al. 2017, Ricordi \& Strom 2004). The cell therapies for the treatment of islet cell loss between the years 2000 and 2017 are listed in Fig. 2.

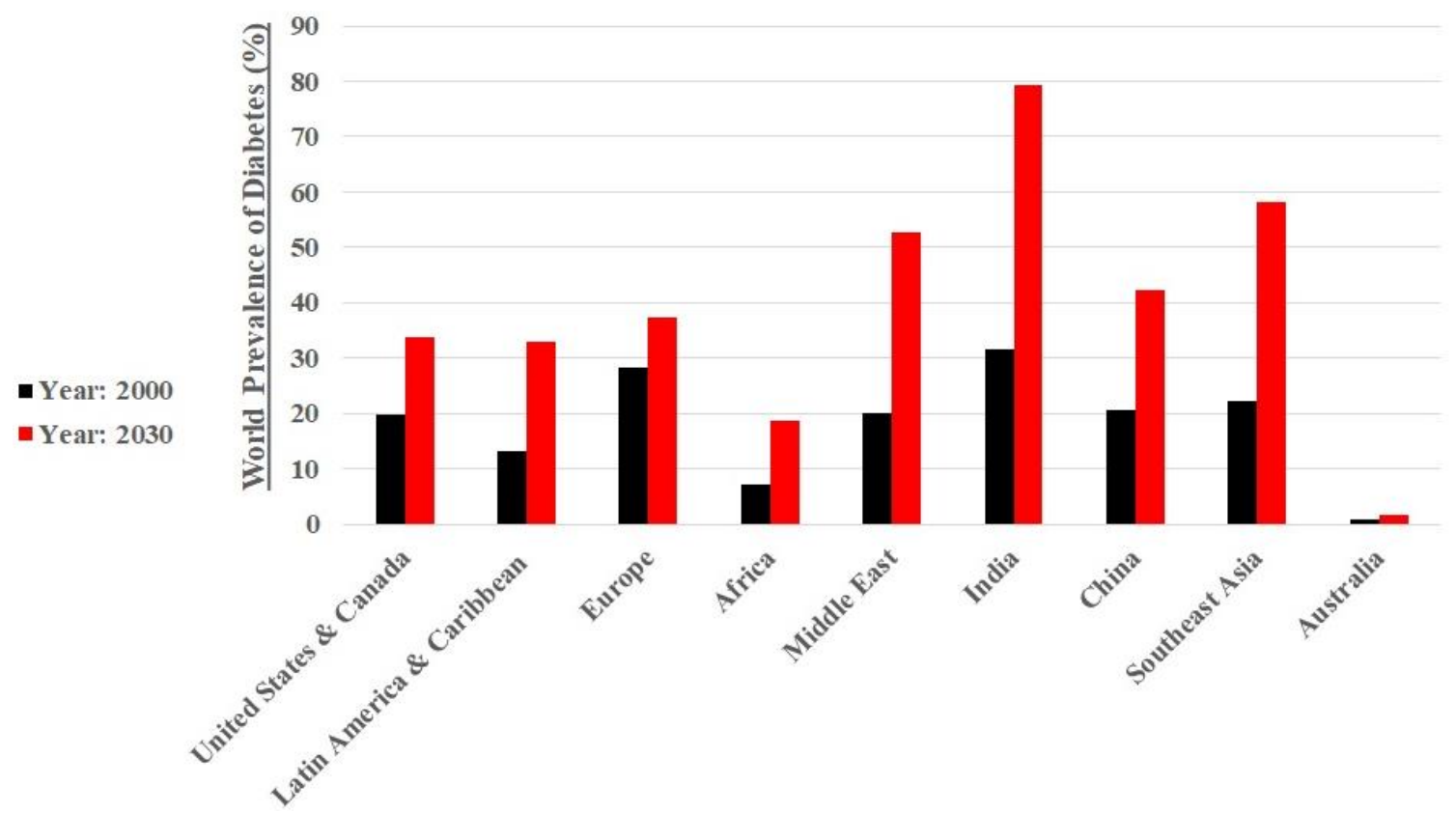

Fig. 1. The worldwide prevalence of DM in 2000 and the estimated prevalance in 2030 (NCD Risk Factor Collaboration 2016). 


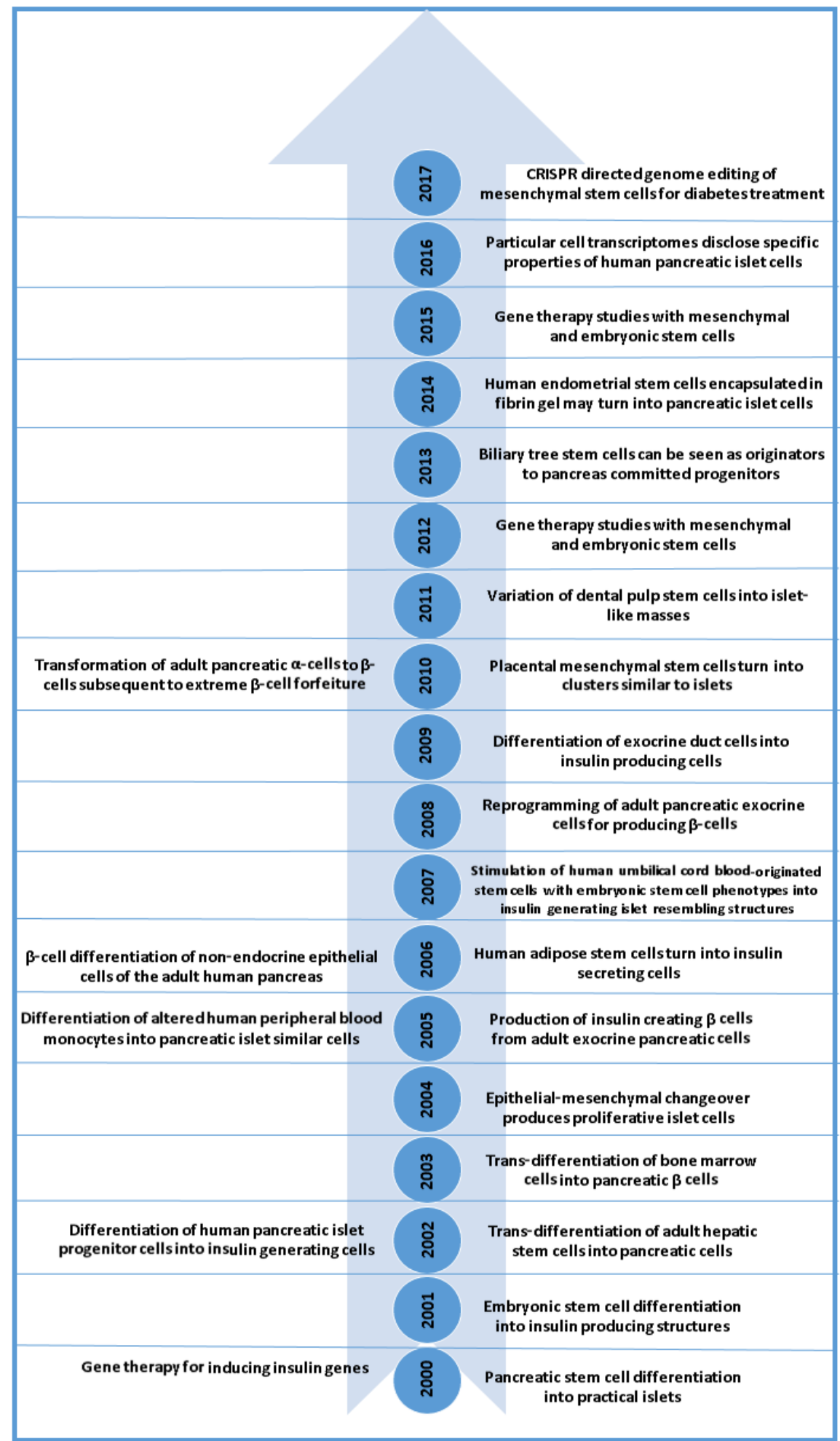

Fig. 2. An overview of the cell therapies for the treatment of islet cell loss between the years 2000 and 2017(Ellis et al. 2017).

\section{Animal Models For The Investigation of Pancreatic Problems}

The non-obese diabetic (NOD) mouse and biobreeding (BB) rat are the most frequently utilized animals that naturally progress diseases with resemblances to human type I DM. In NOD mouse, insulitis exists once the mice are 4-5 weeks old, subsequent to subclinical $\beta$ - cell obliteration and reducing circulating insulin densities. In $\mathrm{BB}$ rat, in corporate with the human disease, ketoacidosis is vigorous and deadly unless exogenous insulin is implemented. Other animal models for type I DM are LETL (Long Evans Takushima Lean) rat, New Zealand white rabbit and Chinese hamster (Rees \& Alcolado 2005). 
Type II DM animal models include $\mathrm{Ob} / \mathrm{Ob}$ mousemonogenic model of obesity (leptin deficient), $\mathrm{db} / \mathrm{db}$ mouse-monogenic model of obesity (leptin resistant), Zucker (fa/fa) rat-monogenic model of obesity (leptin resistant), Goto Kakizaki (GK) rat, KK mouse, NSY mouse, OLETF rat, Israeli sand rat, fat-fed streptozotocintreated rat, CBA/Ca mouse, diabetic Torri rat and New Zealand obese mouse. For GK rat, similar to human type II $\mathrm{DM}$, an excess of maternal transmission has been reported. The NSY mouse is mainly valuable when investigating age correlated phenotypes. Causes for utilizing KK mouse instead of the GK rat lies in the advantage of the KK mouse in imitating human obesity and easier generation of transgenic alternatives from mice rather than rats (Rees \& Alcolado 2005, Seemayer et al. 1980).

\section{Pancreas Transplantation vs. Islet Cell Transplantation}

Today, pancreas transplantation or islets of Langerhans transplantation are the only alternatives to daily insulin injections or insulin pump (Ikemoto et al. 2009). Pancreatic islet transplantation carries a significant advantage of being less invasive and safer for the patients (Matsumoto 2010).

According to Dean et al., the risk of secondary complications of diabetes such as neuropathy, retinopathy and atherosclerotic cardiovascular disease have been shown to decrease by the accomplished pancreas transplantations. Nevertheless, the researchers also reported that most of the data come from a single center and include proportionately small patient cohorts and there have been some conflicting research results (Dean et al. 2017).

The risk/profit ratio must be prudently assessed in each patient where islet transplantation is reflected, as opposing events are often detected succeeding to islet transplantation, mostly associated with immunosuppressive treatment. Strict receiver assessment is vital for choosing patients appropriate for islet transplantation. Ultimate applicants for islet cell transplantation are patients with unbalanced type I DM and have a past of plain glycemic awareness, in spite of attempts to correct the illness via skilled medical treatment (Dean et al. 2017).

A retrospective research reported results from 33 islet transplantation alone (ITA) and 33 PTA receivers. Notably, to emphasize the potential morbidity of PTA strategy, due to graft thrombosis, seven of the PTA receivers $(21 \%)$ required allograft pancreatectomy in the beginning of the post-transplant span. Considering all PTA receivers, insulin independence is achieved in 25 of 33 PTA patients in comparison with 19 of 33 ITA receivers. The probability for lack of insulin independence was estimated similar for PTA and ITA receivers as $\mathrm{P}=0.574$ (Dean et al. 2017).

\section{Stem Cell Therapy}

Different research groups are developing methods to substitute the demolished insulin-secreting cells. Pancreatic islet cell transplantation has so far been the only operative procedure to treat type I DM. Nevertheless, lack of a sustainable source of human islet cells limit this treatment from being utilized in diabetic patients (Vanikar et al. 2016, $\mathrm{Wu} \&$ Mahato 2014). Stem cells have self-renewing features that can create numerous cell types in the body. They are established in adult and fetal tissues, nonetheless stem cells with the broadest evolving capacity originate from an initial stage of the mammalian embryo and called embryonic stem cells (ESCs). Embryonic stem cells may be competently persuaded to distinguish into insulinproducing and further cell lines characteristic of the endocrine pancreas and these cell can be assembled to generate practical pancreatic islet-like structures (Millman \& Pagliuca 2017, Kim et al. 2018, Pysna et al. 2018).

Initially, by a cell trapping system, ESCs were efficiently induced to become distinct into pancreatic $\beta$ cells (Soria et al. 2001). Conversely, this was a complex progression including genetic modification (Soria et al. 2001). Afterwards, (Lumelsky et al. 2001) planned a five step procedure which persuaded ESCs to turn into insulinproducing islet-like structures without genetic modification. Then, the five step method was used by Peterson et al. who discovered that insulin-positive ESCderived cells absorbed insulin from culture medium instead of generating insulin by themselves (Peterson $e t$ al. 2017). For this reason, it is crucial to discover unique stimulation factors that could persuade ESCs to turn into pancreatic $\beta$ cells more efficiently (Shi et al. 2005).

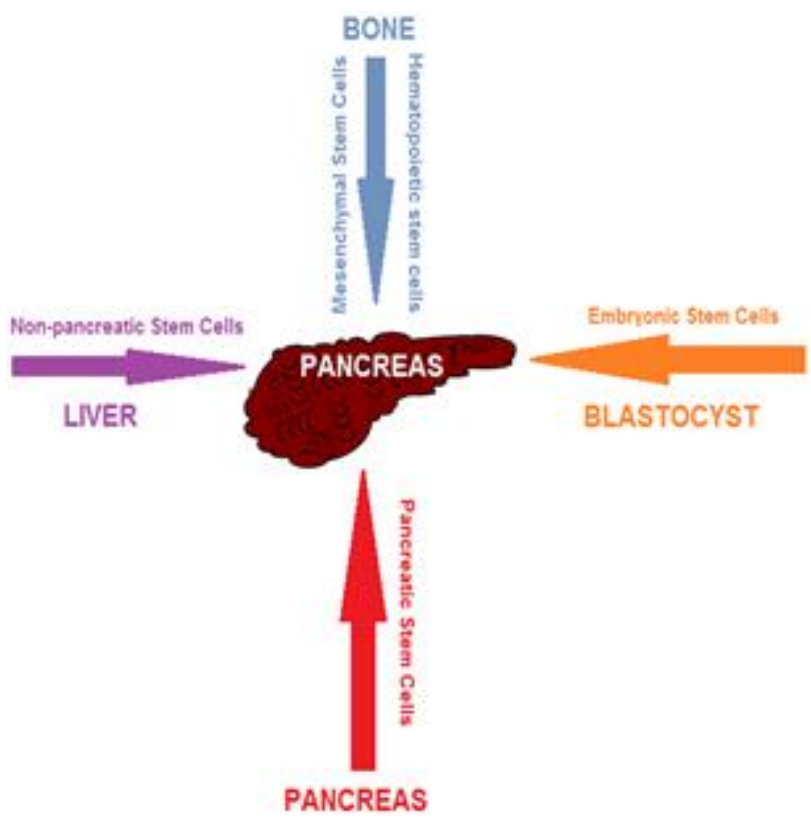

Fig. 3. Different stem cell sources for the islet cell differentiation that has been found so far (McCall et al. 2009).

Multipotent stem cells have been defined inside pancreatic islets and in non-endocrine sections of the pancreas. These cells consume the ability of differentiating into pancreatic islet like structure. Fetal stem cells, particularly umbilical cord blood stem cells, consume a benefit, as being an instrument for stem cell 
treatment in clinic, mostly due to their low immunogenic potential and their moderately easy receiving source. Yoshida et al. (2005) effectively established that the umbilical cord blood stem cells produce insulin generating cells in mice models. Recent researches showed that no rejection occurs even after xenotransplantation of post-differentiated umbilical cord mesenchymal stem cells deprived of immunosuppression treatment (Wang et al. 2004).

Studies proposed that pancreatic stem cells carry the ability to turn into liver cells. Therefore, liver stem cells also carry the potential to differentiate into pancreatic cells, especially endocrine pancreatic cells (Yang et al. 2002). Some contributing causes which promote absolute endoderm differentiation have been reported. As an example, Activin A, a member of transforming growth factor-beta (TGF-B) superfamily, is a crucial factor which enable mesoderm and endoderm formation throughout gastrulation. All-trans retinoic acid (RA) is a well-defined signaling compound, which contributes to anteroposterior modeling of neuroectoderm and mesoderm in vertebrates (Maden 2001).

In spite of their differentiating effectiveness, differentiation of several stem cells into islet cells has two main problems preventing their clinical application: i) these stem cells are not derived from diabetes mellitus patients, and thus transplanting them might inescapably be rejected by the patients, and ii) the source is not adequate to deliver abundant stem cells. Adult stem cells including bone marrow mesenchymal stem cells and pancreatic stem cells carry, regarding to their inherent drawback, a highly immunogenic feature (Burns et al. 2004). Different stem cell sources for islet cell differentiation are listed in Fig. 3.

In order to investigate the factors that might reprogram adult cells into $\beta$ cells, scientists concentrated on transcription factors, a group of genes augmented for factors that control cell providences through embryogenesis. An in-situ hybridization screen of numerous transcription factors recognized clusters of transcription factors with cell type related expressions in the embryonic pancreas. There is a minimum of 20 transcription factors expressed in mature $\beta$ cells and their immediate precursors (Sander \& German 1997).

\section{Cell Reprogramming \& Gene Therapy}

There are several methods of gene therapy for DM. The most mutual approach is the transmission of an insulin gene to the liver utilizing a glucose-responsive promoter to deliberate blood sugar adjustment to the insulin transgene. Conversely, the gradual period path of the transcriptional regulation via glucose makes coordinating insulin production with the recurrent undulations in blood glucose levels an exceptionally challenging job (Cheung et al. 2000).

Regarding this attitude, the insulin gene paradigm should be altered to generate a gene product, that propagates a single chain insulin or that covers novel cleavage situates that permit a liver protease like furin to manufacture mature insulin from proinsulin. Other methodology of somatic gene therapy is the presentation of transcription or growth factors to the liver to persuade the construction of insulin generating cells in the liver (Kojima et al. 2003).

In vivo adult cell reprogramming (transdifferentiation, that is the concept that adult distinguished cells may alter its destiny from one cell type to another) has had diminutive investigational support from mouse models (Thorel et al. 2010). Neurogenin 3 (Ngn 3 ) is recognized as an important transcription factor in the expansion of pancreatic endocrine cells, and the absence of endocrine cells has been established in Ngn 3-deficient mice. An experiment utilizing ESCs where Ngn3 expression was controllable revealed that the expression of genes linked with the pancreatic $\beta$-cell growth was upregulated upon expression of the Ngn3 gene. This process induces differentiation and the subsequent insulin-producing cells have been found receptive. Nevertheless, the differentiation effectiveness has been established expressively restricted (Schonhoff et al. 2004).

Some studies developed exocrine cells of an adult pancreas as target cells for reprogramming. Exocrine cells originate from pancreatic endoderm as do $\beta$ cells, and may turn on endocrine programs once detached and cultured in vitro. The transcription factors were carried into the pancreas in adenoviral vectors. It has been revealed that adenovirus specially infects pancreatic exocrine cells, but not islet cells, and since most endogenous $\beta$ cells exist in islets, fresh formed $\beta$ cells might be simply identified as extra islet insulin positive cells. The three reprogramming elements, Pdx1, Mafa and Ngn3 were identified to be significant in the embryogenesis of pancreas and $\beta$ cells. Meanwhile, various extra dynamics are also needed for $\beta$ cell expansion (Zhou et al. 2008). $\alpha$-cells were at no time thought as a possible basis of cells for $\beta$-cell therapy in diabetes. Recent studies showed that the quantity of $\beta$ cells originated from reprogrammed $\alpha$-cells is very variant between people having the similar level of $\beta$-cell obliteration. Expression of Pdx1 can be important for the $\alpha$-cell translation process. Ectopic Pdx 1 activity, on its own or joint with other elements, arises hepatocytes or acinar cells into insulin production. $\alpha$ - and $\beta$ - cells are functionally very parallel, with a related equipment to process glucose and secrete hormones. Expression of Glut2 in insulin generating reprogrammed $\alpha$-cells, combined with Nkx6.1 and Pdx1, would permit them to discharge insulin upon glucose stimulation same as efficient $\beta$-cells (Thorelet al. 2010).

One recent study demonstrated a tumor derived K cell (mainly positioned in stomach) which was persuaded to generate human insulin through providing the cells with the human insulin gene associated with the 5' regulatory region of the gene coding glucose reliant insulinotropic polypeptide (GIP) (Cheung et al. 2000). Mice expressing this transgene manufactured human insulin especially in 
gut K cells. This insulin endangered mice form evolving diabetes and preserved glucose tolerance subsequent to obliteration of the innate insulin generating $\beta$ cells (Cheung et al. 2000).

One study has indicated that, the distribution of a combination of the BETA2 and Btc genes to liver persuaded islet neogenesis and upturned diabetes in mice models (Kojima et al. 2003). Another research group has transfected human fetal pancreases with a lentiviral vector which expressed SV40LT in the regulation of the insulin promoter. The transduced pancreases have been embedded into SCID mice afterwards with the aim of turning them into pancreatic tissue. The human $\beta$-cells have found differentiated with expressing SV40LT parallel with insulin production, have proliferated and produced insulinomas. The insulinomas have then been incubated with a lentiviral vector that expressed human telomerase reverse transcriptase (hTERT), and the hTERT-transduced insulinoma cells have been attached to other SCID mice to amplify the proliferation of $\beta$-cells (Ravassard et al. 2011).

\begin{tabular}{|l|l|}
\hline 2002 & $\begin{array}{l}\text { TGF- } \beta 1 \text {-transfected mouse islets are protected from apoptosis, autoimmune destruction and } \\
\text { disease recurrence } \\
\text { NeuroD-betacellulin gene therapy in the liver induced islet neogenesis and reversed diabetes } \\
\text { in mice } \\
\text { TGF-betal gene therapy promoted islet regeneration and protected against autoimmune } \\
\text { destruction }\end{array}$ \\
\hline 2003 & $\begin{array}{l}\text { Angiotensin I-converting enzyme type 2 (ACE2) gene therapy enhanced glycemic control } \\
\text { and prevented } \beta \text { cell dysfunction }\end{array}$ \\
\hline 2010 & $\begin{array}{l}\text { A novel technique in liver directed gene therapy permanently reversed T1D } \\
\text { Non-viral gene therapy directed at pancreatic islets using UTMD in baboons normalized } \\
\text { their glucose tolerance and restored B-cell mass }\end{array}$ \\
\hline 2013 & $\begin{array}{l}\text { PAX4 Gene Transfer to alpha cells phenotypically changed their functions to those of B cells } \\
\text { improve glucose tolerance }\end{array}$ \\
\hline 2016 & $\begin{array}{l}\text { TCR gene transfer induced the production islet-specific regulatory T cells to increase the } \\
\text { efficacy of type 1 diabetes treatment }\end{array}$ \\
\hline 2017 & $\begin{array}{l}\text { Lentivirus-Mediated Glucagon-Like Peptide-1 Gene Therapy in diabetic mice models } \\
\text { improved their insulin sensitivity and glucose tolerance }\end{array}$ \\
\hline HIV-based intestinal peptide gene therapy worked against STZ-induced diabetes
\end{tabular}

Fig. 4. An overview of gene therapies for the treatment of DM used between the years 2000 and 2018 (Green et al. 2018).

Amongst the immunomodulatory mediators, the Th-2 like cytokine IL-10 has been one of the most comprehensively examined and encouraging candidates for operative immune alteration of diabetes treatment. Immune modulation deliberated by adeno-associated virus IL-10 gene therapy has efficiently and intensely enhanced transplant endurance and postponed reappearance of diabetes after islet transplantation in NOD mice (Zhang et al. 2003). An overview of the gene therapies for the treatment of diabetes through the years are presented in Fig. 4.

\section{Bioartificial Pancreas}

Numerous people around the world agonize from hormone-deficiencies. At present, many of these hormone deficiency diseases may be regulated with systematic intakes of the missing hormone by the patients. Conversely, oral replacement treatment can only postpone the initiation of problems of the illness. At this time, the only certain therapy for these diseases is half-done or total organ transplantation, while the risks elaborated in transplantation are great. A serious risk in organ transplantation is the issue of the host's immune system to reject the transplanted organ. Consequently, receivers will have to use immunomodulating medications for the rest of their lives to evade organ refusal (Kutsogiannis et al. 2006).

During the past 30 years, scientists have been trying to improve alternative strategies to stop the requirement of immunosuppressing medication rules after organ transplantation. These so called bioartificial organs on the other hand, mostly cover cells or cell groups inside of a synthetic biocompatible semipermeable membrane that splits the extraneous tissue from the host's immune system (Sander \& German 1997). These organs may be implanted in the blood or inserted somewhere in the body via diffusion potential and are meant to entirely imitate the performance and purpose of a healthy organ. Intravascular tools are inserted as an artery-to-vein (AV) shunt in the receiver's body and are commonly originated from tubular hollow fiber membranes. Such extravascular tools may be further categorized in two diverse groups, macro- and micro-capsular devices. Macro-capsular ones can have three key geometries; flat sheet, sealed hollow fibers and macrospheres. These are 

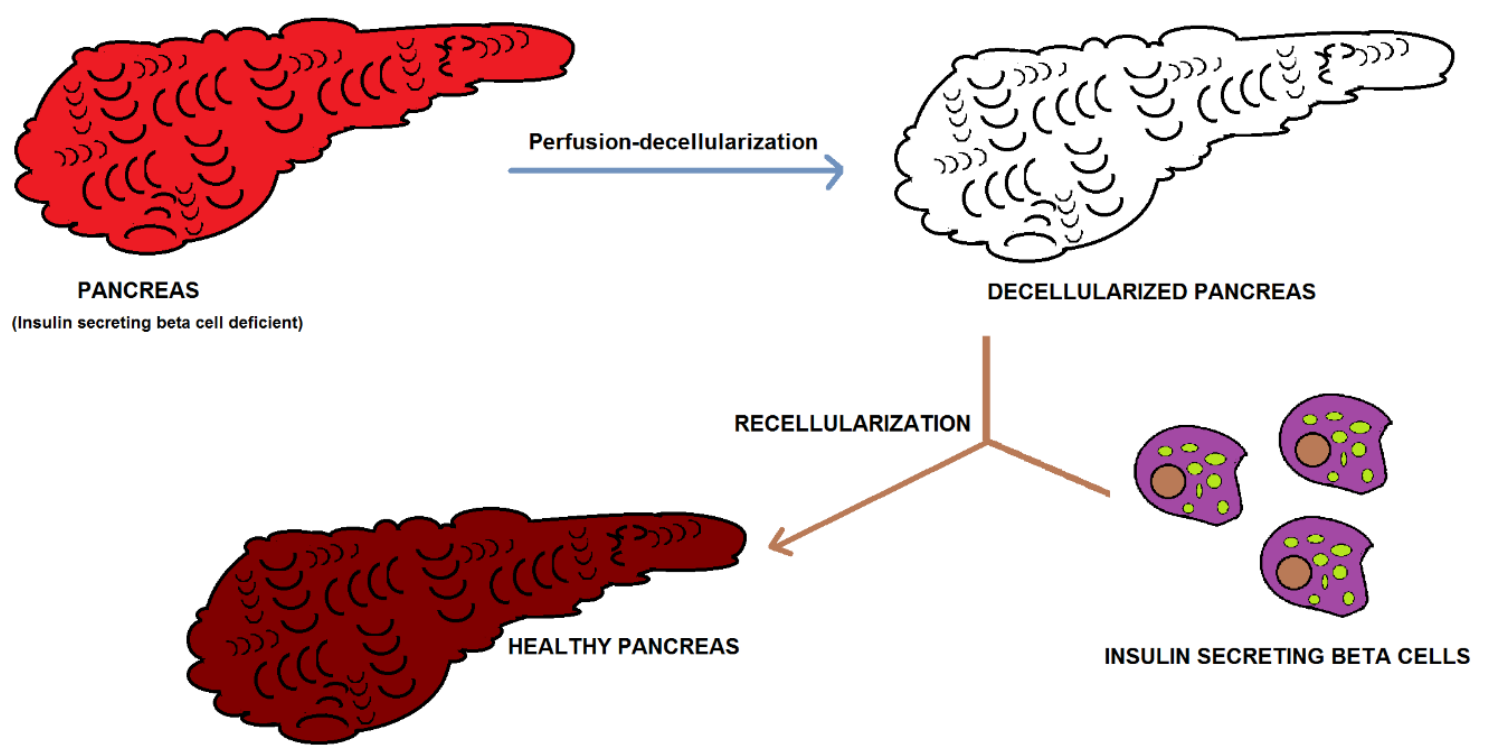

Fig. 5. Tissue engineering of pancreas. The idea is to generate an artificial pancreas. A pancreas is decellularized by perfusion. The subsequent non-immunogenic matrix preserves the organ specific extracellular matrix containing the vascular and ductular proteins. The matrix is then repopulated by mixture of islets to produce a practical and implantable organ (from Song \& Ott 2011).

mostly entrenched in the peritoneal cavity but have been inserted in additional areas as well (Li et al. 2004, Williams et al. 2004). Even though encouraging outcomes have been achieved in early animal studies, the crucial worth of islet encapsulation has been restricted due to 1) deprived biocompatibility of capsule constituents, 2) insufficient immune-isolation regarding to the diffusion of small immune intermediaries, like chemokines, cytokines and nitric oxide, and 3) hypoxia secondary to unsuccessful revascularization (Mirmalek-Sani et al. 2013).

Effective islet replacement re-establishes standard glucose uptake in patients with insulin reliant diabetes mellitus (IDDM) then necessitates chronic immunosuppression that is linked with illness and death. The utilization of bioartificial pancreas (BAP) has arisen as a possible choice in clinical islet transplantation regarding to its effectiveness in eradicating immunosuppression. The construction of BAP requires great comprehension of how to preserve the encapsulated islets feasible and operative correctly for elongated periods of time along with facilitating embedding and recovery (Qi et al. 2004).

Macro-encapsulation is the envelopment of a huge quantity of islets in a diffusion cavity of a discriminatory membrane for immune-isolation. Microcapsules propose the benefit of embedding and recovery with negligible surgical risk. They can be embedded not only in the peritoneal fissure but also in subcutaneous spot. Different chemical constituents, such as a copolymer of acrylonitrile and vinyl chloride, agarose, alginate, etc., have been utilized as a blockade to avoid refusal of islets (Calafiore et al. 2004).

\section{Tissue Engineering of Pancreas}

Advances in tissue engineering have facilitated the development of replacement organ tissues for the treatment of injured or degenerative soft tissue. The development of a bioengineered pancreas by appropriate combinations of cells, biomaterial scaffolds and biologically active molecules could provide an alternative avenue for DM therapy (Iacovacci et al. 2016). Researchers examined the probability of producing an acellular complete pancreas scaffold via the perfusion, decellularization method and then using this biomaterial as a scaffold to upkeep pancreatic tissue engineering and entire organ regeneration. In the direction of this conclusion, they identified a subsequent native pancreatic ECM scaffold for conservation of ECM arrangement, 3D structural unity and biomechanical features. The conserved ECM scaffold was cyto-compatible, supportive of typical pancreatic cells and showed improved insulin utility once seeded with $\beta$ cells (Mirmalek-Saniet al. 2013).

In a different study, the islets have been grown in chitosan sponge for additional applications. Throughout the process, insulin density of both the interior and exterior of the islet-seeded chitosan sponge have been evaluated. Alterations in the morphology of the islets have been detected. The study also designated that, islets had a moveable presence with an uneven edge, and most were seen as a solitary islet. Infrequently a cluster, involving 24 islets changing mostly from 150 to $250 \mu \mathrm{m}$ in diameter have been detected (Cui et al. 2001).

Organogenesis of an endocrine pancreas from transplanted embryonic anlagen was effectively accomplished by Hammerman in 2007. A technique has been established which allows the replacement of developing fetal or neonatal pancreatic tissue that has an amplified capability for pancreatic $\beta$-cell growth (Hammerman 2007). Tissue engineering model system is explained in Fig. 5. 


\section{Discussion}

Regarding the fact that diabetes is an illness that strikes millions of people universally and requires a lifetime inevitability of insulin injections and a high possibility of side effects since glucose blood level regulation is not as good as the physiological glucose regulation. $\beta$-cell replacement therapy is extremely necessary. The past 20 years have perceived important improvements in the methodical understanding and management of diabetes. There are two main enterprises on track to fix the $\beta$-cell shortage of diabetes: one to produce $\beta$-cells ex vivo that are proper for replacement, and the next to induce renewal of $\beta$-cells in the pancreas (Mann et al. 2009).

The choice of transplanting a pancreas or isolated islets is restricted due to the absence of appropriate organs relative to the great quantity of possible receivers, joint with heavy repercussions triggered by an enduring immunosuppression that has to be weighed contrary to the requirement of insulin injections and it is for that reason solitary suggestible for a subclass of patients with plain medical antiquity (Larsen 2004).

Despite the fact that islet transplantation cannot presently be explained as a complete treatment for DM, the therapy may suggest notable constancy of glycaemic regulation, procuring a cumulative number of patients with continued phases of complete permissiveness from insulin. Preservation of serious hypoglycaemia is the main development that may frequently not be maintained via exogenous insulin treatment (Wagman \& Nuss 2001).

New developments in reprogramming through explained genes jointly underline that a restricted amount of factors may program adult cells into another type of cell covering progenitor cells, other mature cells and stem cells. These recent advances based on information of the

\section{References}

1. Akinci, E., Banga, A., Greder, L.V., Dutton, J.R. \& Slack, J.M.W. 2012. Reprogramming of pancreatic exocrine cells towards a beta (beta) cell character using Pdx1, Ngn3 and MafA. Biochemical Journal, 442: 539-550.

2. Burns, C.J., Persaud, S.J. \& Jones, P.M. 2004. Stem cell therapy for diabetes: do we need to make beta cells? Journal of Endocrinology, 183: 437-443.

3. Calafiore, R., Basta, G., Luca, G., Calvitti, M., Calabrese, G., Racanicchi, L., Macchiarulo, G., Mancuso, F., Guido, L. \& Brunetti, P. 2004. Grafts of microencapsulated pancreatic islet cells for the therapy of diabetes mellitus in non-immunosuppressed animals. Biotechnology and Applied Biochemistry, 39: 159-164.

4. Cheung, A.T., Dayanandan, B., Lewis, J.T., Korbutt, G.S., Rajotte, R.V., Bryer-Ash, M., Boylan, M.O., Wolfe, M.M. \& Kieffer, T.J. 2000. Glucose-dependent insulin release from genetically engineered K cells. Science, 290: 19591962. typical expansion of these cell forms have allowed the alteration of crucial developmental controllers in adult cells (Akinci et al. 2012).

A more tempting approach includes the replacement of $\beta$ cells grown from stem cells, particularly with recent advances in generating large numbers of $\beta$ cells from human stem cells. Scientific investigations of the safety, admissibility, and efficiency of relocating cells in encapsulated arrangements in type I DM patients are currently in progress (Soria et al. 2001).

Regarding the fact that there exist a multitude of methodologies in regenerative medicine including the induction of beta-cell proliferation, reprogramming of other pancreatic or non-pancreatic cells, the differentiation investigation on iPSC, fetal stem cells, or adult stem cells, it is not likely to estimate which technique will appear ahead. Mesenchymal stem cells carry an excessive capacity and are not limited by the ethical problems like embryonic stem cells (Hussain \& Theise 2004).

\section{Conclusion}

It is understood that a significant dissimilarity exists amongst autoimmune diabetes that is curable with insulin, and serious diseases. Before the cell therapy, the risks and benefits should be accurately considered. For instance, continuing management with immunosuppressive mediators might result in an augmented degree of malignancies. Therefore, stem cell technology and tissue engineering approaches may hold the solution to treat diabetes.

\section{Acknowledgement}

We would like to thank to Prof. Türker KILIÇ, the Dean of Bahçeşehir University Faculty of Medicine for his scientific support.

5. Cui, W., Kim, D.H., Imamura, M., Hyon, S.H. \& Inoue, K. 2001. Tissue-engineered pancreatic islets: culturing rat islets in the chitosan sponge. Cell Transplantation, 10: 499502.

6. Dean, P.G., Kukla, A., Stegall, M.D. \& Kudva, Y.C. 2017. Pancreas transplantation. British Medical Journal, 357pp.

7. Ellis, C., Ramzy, A. \& Kieffer, T.J. 2017. Regenerative medicine and cell-based approaches to restore pancreatic function. Nature Reviews Gastroenterology \& Hepatology, 14: 612-628.

8. Fioretto, P., Steffes, M.W., Sutherland, D.E.R., Goetz, F.C. \& Mauer, M. 1998. Reversal of lesions of diabetic nephropathy after pancreas transplantation. New England Journal of Medicine, 339: 69-75.

9. Green, A.D., Vasu, S. \& Flatt, P.R. 2018. Cellular models for beta-cell function and diabetes gene therapy. Acta physiologica, 222. https://doi.org/10.1111/apha.13012 
10. Hafiz, M.M., Faradji, R.N., Froud, T., Pileggi, A., Baidal, D.A., Cure, P., Ponte, G., Poggioli, R., Cornejo, A., Messinger, S., Ricordi, C. \& Alejandro, R. 2005. Immunosuppression and procedure-related complications in 26 patients with type 1 diabetes mellitus receiving allogeneic islet cell transplantation. Transplantation, 80: 1718-1728.

11. Halpin, A., Floora, H., Hidalgo, L., Shapiro, J., Senior, P., Bigam, D. \& Campbell, P. 2017. Patient Tailored Crossmatch, Do Islet Cell and Pancreas Transplants Call for a Different Fit? Transplantation, 101: 29.

12. Hammerman, M.R. 2007. Organogenesis of kidney and endocrine pancreas: the window opens. Organogenesis, 3: 59-66.

13. Hussain, M.A. \& Theise, N.D. 2004. Stem-cell therapy for diabetes mellitus. Lancet, 364: 203-205.

14. Iacovacci, V., Ricotti, L., Menciassi, A. \& Dario, P. 2016. The bioartificial pancreas (BAP): Biological, chemical and engineering challenges. Biochemical Pharmacology, 100: 12-27.

15. Ikemoto, T., Noguchi, H., Shimoda, M., Naziruddin, B., Jackson, A., Tamura, Y., Fujita, Y., Onaca, N., Levy, M.F. \& Matsumoto, S. 2009. Islet cell transplantation for the treatment of type 1 diabetes in the USA. Journal of HepatoBiliary-Pancreatic Surgery, 16: 118-123.

16. Kim, H.J., Li, Q., Song, W.J., Yang, H.M., Kim, S.Y., Park, S.C., Ahn, J.O. \& Youn, H.Y. 2018. Fibroblast growth factor- 1 as a mediator of paracrine effects of canine adipose tissue-derived mesenchymal stem cells on in vitro-induced insulin resistance models. BMC Veterinary Research, 14: 351.

17. Kojima, H., Fujimiya, M., Matsumura, K., Younan, P., Imaeda, H., Maeda, M. \& Chan, L. 2003. NeuroDbetacellulin gene therapy induces islet neogenesis in the liver and reverses diabetes in mice. Nature Medicine, 9: 596-603.

18. Kutsogiannis, D.J., Pagliarello, G., Doig, C., Ross, H. \& Shemie, S.D. 2006. Medical management to optimize donor organ potential: review of the literature. Canadian Journal of Anaesthesia-Journal Canadien D Anesthesie, 53: 820-830.

19. Larsen, J.L. 2004. Pancreas transplantation: indications and consequences. Endocrine Reviews, 25: 919-946.

20. Li, Y., Koshiba, T., Yoshizawa, A., Yonekawa, Y., Masuda, K., Ito, A., Ueda, M., Mori, T., Kawamoto, H., Tanaka, Y., Sakaguchi, S., Minato, N., Wood, K.J. \& Tanaka, K. 2004. Analyses of peripheral blood mononuclear cells in operational tolerance after pediatric living donor liver transplantation. American Journal of Transplantation, 4: 2118-2125.

21. Lumelsky, N., Blondel, O., Laeng, P., Velasco, I., Ravin, R. \& McKay, R. 2001. Differentiation of embryonic stem cells to insulin-secreting structures similar to pancreatic islets. Science, 292: 1389-1394.

22. Maden, M. 2001. Role and distribution of retinoic acid during CNS development. International Review of Cytology, 209: 1-77.

23. Mann, D.M., Ponieman, D., Leventhal, H. \& Halm, E.A. 2009. Misconceptions about diabetes and its management among low-income minorities with diabetes. Diabetes Care, 32: 591-593.

24. Matsumoto, S. 2010. Islet cell transplantation for Type 1 diabetes. Journal of Diabetes, 2: 16-22.

25. McCall, M.D., Toso, C., Baetge, E.E. \& Shapiro, A.M. 2009. Are stem cells a cure for diabetes? Clinical Science, 118: 87-97.

26. Millman, J.R. \& Pagliuca, F.W. 2017. Autologous Pluripotent Stem Cell-Derived -Like Cells for Diabetes Cellular Therapy. Diabetes, 66: 1111-1120.

27. Mirmalek-Sani, S.H., Orlando, G., McQuilling, J.P., Pareta, R., Mack, D.L., Salvatori, M., Farney, A.C., Stratta, R.J., Atala, A., Opara, E.C. \& Soker, S. 2013. Porcine pancreas extracellular matrix as a platform for endocrine pancreas bioengineering. Biomaterials, 34: 5488-5495.

28. NCD Risk Factor Collaboration (NCD-RisC) 2016. Worldwide trends in diabetes since 1980: a pooled analysis of 751 population-based studies with 4.4 million participants. Lancet, 387(10027): 1513-1530. https://doi.org/10.1016/S0140-6736(16)00618-8

29. Oksuz, E., Malhan, S., Urganci, B. \& Tetik, E. 2017. CostMinimization Analysis of Linagliptin Compared to Sitagliptin in the Treatment of Type 2 Diabetes Mellitus from a Turkish Healthcare Perspective. Journal of Diabetes \& Metabolism, 8: 739. https://doi.org/10.4172/21556156.1000739

30. Petersmann, A., Nauck, M., Muller-Wieland, D., Kerner, W., Muller, U.A., Landgraf, R., Freckmann, G. \& Heinemann, L. 2018. Definition, Classification and Diagnosis of Diabetes Mellitus. Experimental and Clinical Endocrinology \& Diabetes, 126: 406-410.

31. Petersen, M.B.K., Azad, A., Ingvorsen, C., Hess, K., Hansson, M., Grapin-Botton, A. \& Honoré, C. (2017). Single-cell gene expression analysis of a human ESC model of pancreatic endocrine development reveals different paths to $\beta$-cell differentiation. Stem cell reports, 9(4): 1246-1261.

32. Pysna, A., Bem, R., Nemcova, A., Fejfarova, V., Jirkovska, A., Hazdrova, J., Jude, E.B. \& Dubsky, M. 2018. Endothelial Progenitor Cells Biology in Diabetes Mellitus and Peripheral Arterial Disease and their Therapeutic Potential. Stem Cell Reviews, 9. https://doi.org/10.1007/s12015-018-9863-4

33. Qi, M., Gu, Y., Sakata, N., Kim, D., Shirouzu, Y., Yamamoto, C., Hiura, A., Sumi, S. \& Inoue, K. 2004. PVA hydrogel sheet macroencapsulation for the bioartificial pancreas. Biomaterials, 25: 5885-5892.

34. Ravassard, P., Hazhouz, Y., Pechberty, S., Bricout-Neveu, E., Armanet, M., Czernichow, P. \& Scharfmann, R. 2011. A genetically engineered human pancreatic beta cell line exhibiting glucose-inducible insulin secretion. Journal of Clinical Investigation, 121: 3589-3597.

35. Rees, D.A. \& Alcolado, J.C. 2005. Animal models of diabetes mellitus. Diabetic Medicine, 22: 359-370.

36. Ricordi, C. \& Strom, T.B. 2004. Clinical islet transplantation: Advances and immunological challenges. Nature Reviews Immunology, 4: 258-268. 
37. Sander, M. \& German, M.S. 1997. The beta cell transcription factors and development of the pancreas. Journal of Molecular Medicine (Berlin), 75: 327-340.

38. Schonhoff, S.E., Giel-Moloney, M. \& Leiter, A.B. 2004. Neurogenin 3-expressing progenitor cells in the gastrointestinal tract differentiate into both endocrine and non-endocrine cell types. Developmental Biology, 270: 443-454.

39. Seemayer, T.A., Oligny, L.L., Tannenbaum, G.S., Goldman, H. \& Colle, E. 1980. Animal-Model of HumanDisease - Diabetes-Mellitus. American Journal of Pathology, 101: 485-488.

40. Shapiro, A.M.J., Lakey, J.R.T., Ryan, E.A., Korbutt, G.S., Toth, E., Warnock, G.L., Kneteman, N.M. \& Rajotte, R.V. 2000. Islet transplantation in seven patients with type 1 diabetes mellitus using a glucocorticoid-free immunosuppressive regimen. New England Journal of Medicine, 343: 230-238.

41. Shi, Y., Hou, L., Tang, F., Jiang, W., Wang, P., Ding, M. \& Deng, H. 2005. Inducing embryonic stem cells to differentiate into pancreatic beta cells by a novel three-step approach with activin A and all-trans retinoic acid. Stem Cells, 23: 656-662.

42. Silva, A.I., de Matos, A.N., Brons, I.G. \& Mateus, M. 2006. An overview on the development of a bio-artificial pancreas as a treatment of insulin-dependent diabetes mellitus. Medicinal Research Reviews, 26: 181-222.

43. Song, J.J. \& Ott, H.C. 2011. Organ engineering based on decellularized matrix scaffolds. Trends in Molecular Medicine, 17: 424-432.

44. Soria, B., Skoudy, A. \& Martin, F. 2001. From stem cells to beta cells: new strategies in cell therapy of diabetes mellitus. Diabetologia, 44: 407-415.

45. Thorel, F., Nepote, V., Avril, I., Kohno, K., Desgraz, R., Chera, S. \& Herrera, P.L. 2010. Conversion of adult pancreatic alpha-cells to beta-cells after extreme beta-cell loss. Nature, 464: 1149-1154.

46. Vanikar, A.V., Trivedi, H.L. \& Thakkar, U.G. 2016. Stem cell therapy emerging as the key player in treating type 1 diabetes mellitus. Cytotherapy, 18: 1077-1086.
47. Wagman, A.S. \& Nuss, J.M. 2001. Current therapies and emerging targets for the treatment of diabetes. Current Pharmaceutical Design, 7: 417-450.

48. Wang, H.S., Hung, S.C., Peng, S.T., Huang, C.C., Wei, H.M., Guo, Y.J., Fu, Y.S., Lai, M.C. \& Chen, C.C. 2004. Mesenchymal stem cells in the Wharton's jelly of the human umbilical cord. Stem Cells, 22: 1330-1337.

49. Williams, J.M., Holzknecht, Z.E., Plummer, T.B., Lin, S.S., Brunn, G.J. \& Platt, J.L. 2004. Acute vascular rejection and accommodation: divergent outcomes of the humoral response to organ transplantation. Transplantation, 78: 1471-1478.

50. Wu, H. \& Mahato, R.I. 2014. Mesenchymal Stem Cellbased Therapy for Type 1 Diabetes. Discovery Medicine, 17: 139-143.

51. Yang, L., Li, S., Hatch, H., Ahrens, K., Cornelius, J.G., Petersen, B.E. \& Peck, A.B. 2002. In vitro transdifferentiation of adult hepatic stem cells into pancreatic endocrine hormone-producing cells. Proceedings of the National Academy of Sciences of the United States of America, 99: 8078-8083.

52. Yoshida, S., Ishikawa, F., Kawano, N., Shimoda, K., Nagafuchi, S., Shimoda, S., Yasukawa, M., Kanemaru, T., Ishibashi, H., Shultz, L.D. \& Harada, M. 2005. Human cord blood--derived cells generate insulin-producing cells in vivo. Stem Cells, 23: 1409-1416.

53. Zhang, Y.C., Pileggi, A., Agarwal, A., Molano, R.D., Powers, M., Brusko, T., Wasserfall, C., Goudy, K., Zahr, E., Poggioli, R., Scott-Jorgensen, M., CampbellThompson, M., Crawford, J.M., Nick, H., Flotte, T., Ellis, T.M., Ricordi, C., Inverardi, L. \& Atkinson, M.A. 2003. Adeno-associated virus-mediated IL-10 gene therapy inhibits diabetes recurrence in syngeneic islet cell transplantation of NOD mice. Diabetes, 52: 708-716.

54. Zhou, Q., Brown, J., Kanarek, A., Rajagopal, J. \& Melton, D.A. 2008. In vivo reprogramming of adult pancreatic exocrine cells to beta-cells. Nature, 455: 627-632. 